\title{
SLC28A3 Gene
}

National Cancer Institute

\section{Source}

National Cancer Institute. SLC28A3 Gene. NCI Thesaurus. Code C113321.

This gene plays a role in sodium-dependent nucleoside transport. 